\title{
LOS RELATOS DE VIAJE DE GERTRUDIS GÓMEZ DE AVELLANEDA
}

\author{
Ángeles EZAMA GIL
}

Universidad de Zaragoza

\section{RESUMEN}

En este artículo pretendo ofrecer una perspectiva poco habitual en relación con la escritura de Gertrudis Gómez de Avellaneda, la de autora de relatos de viaje. Son tres los escritos de este tipo pergeñados por la escritora, uno editado como Memorias inéditas en 1914 y otros dos publicados en la prensa en 1857 y 1860. Los tres están escritos en primera persona y el primero es, con diferencia, el más intimista. Los relatos de 1857 y 1860 son los menos conocidos debido a su publicación periodística, sobre todo el primero de ellos, aparecido en las páginas del periódico El Estado, en el que hasta ahora ningún crítico había reparado; son una impresiones de viaje escritas en forma epistolar y dirigidas al escritor cubano Teodoro Guerrero. El publicado en 1914 es un relato del exilio que lleva a la autora desde Cuba hasta España, en tanto que los otros dos narran viajes veraniegos de placer; son comunes a ellos la presencia de tradiciones y de episodios históricos, constituyen además un ejemplo de literatura de balneario y de crónica social. En los tres se aglutinan variedad de materiales narrativos a los que concede cohesión la mirada de una narradora romántica que sublima el entorno contemplado y lo reproduce en términos pintorescos e incluso fantásticos, ya que su contemplación se halla mediatizada por la concepción idealizada del pueblo vasco y del entorno natural y por algunos referentes literarios. Con todo ello, dichos relatos de viaje evidencian su condición de género fronterizo, híbrido, de gran diversidad genérica y discursiva, trufados de elementos heterogéneos en una suerte de relatomiscelánea en que la aventura del viajero es un pretexto para hilvanar piezas diversas. Palabras clave: Relato de viaje. Exilio. Provincias Vascongadas. Sur de Francia. Tradición. Literatura de balneario. Crónica social. Viaje no escrito. 


\begin{abstract}
In this article I offer an unusual perspective in relation with Gertrudis Gómez de Avellaneda's writing, that of authoress of statements of trip. They are three the writings of this type arranged by the writer, one edited as Memorias ineditas in 1914 and the other two published in the periodical press in 1857 and 1860. The three are written in the first person and the first one is by far the most intimate. The stories of 1857 and 1860 are the least known because of his journalistic publication, especially the first one, published in the pages of the newspaper The State, which so far no critic had noticed; there are travel impressions written in the form of letters addressed to the Cuban writer Teodoro Guerrero. The narrative published in 1914 is a statement of the exile that takes the authoress from Cuba up to Spain, while the other two narrate summer trips of pleasure; they are common to them the presence of traditions and historical episodes, constitute in addition an example of literature of resort and of gossip column. All the three agglutinate variety of narrative materials which cohesion depends the look of a romantic narrator that sublimates the contemplated environment and reproduces it in picturesque and even fantastic terms, since his contemplation is mediatized by the idealized conception of the Basque people and of the natural environment and by some literary references. All in all, these travel narratives demonstrate his condition of frontier, hybrid kind, of great generic and discursive diversity, stuffed with heterogeneous elements in a kind of story-miscellany in which the adventure traveler is an excuse to string together various pieces.
\end{abstract}

Key words: Statement of trip. The exile. Basque Country. South of France. Tradition. Literature of resort. Gossip column. The never written travel.

\title{
GERTRUDIS GÓMEZ DE AVELLANEDA Y LA LITERATURA DE VIAJE
}

«Lo que suele entenderse como literatura de viajes no es generalmente asociada con la obra de Gertrudis Gómez de Avellaneda [...] Este trabajo aspira a detenerse en aquellos aspectos de la obra de Avellaneda que en mayor o menor medida claramente revelan como intertexto la presencia de la literatura de viajes», declaraba Raúl Ianes en 1997 (209). No cabe duda de que el viaje tiene una importancia medular en la biografía de la escritora Gertrudis Gómez de Avellaneda. De origen cubano, pasó a residir en España en 1836, desde donde realizó un viaje que la llevó de nuevo a Cuba, entre 1859 y 1864, volviendo a España previa una estancia en Nueva York, Londres y París. Viajó, además, a Francia en varias ocasiones: con su marido Pedro Sabater en 1846 para tratar de curar la enfermedad de este, permaneciendo tras su muerte en un convento en Burdeos (1847), y en sus desplazamientos veraniegos, que la llevaban a las Provincias Vascongadas o a los Pirineos, para entrar luego en Francia; de estos hay dos documentados, uno en 1857 y otro en 1859, ambos con su segundo marido Domingo Verdugo. 
El primer desplazamiento de Avellaneda es el que la traslada de Cuba a España, considerado por la escritora como un exilio; así lo manifiesta en el prólogo a la traducción castellana de La Havane de la condesa de Merlin, también como ella exiliada:

Nada, en efecto, es tan amargo como la expatriación, y siempre hemos pensado como la gran escritora que juzgaba los viajes uno de los más tristes placeres de la vida. [...]

Existencia sin comienzo, espectáculo sin interés, detrás de sí unos días que nada tienen que ver con lo presente, delante otros que no encuentran apoyo en lo pasado, los recuerdos y las esperanzas divididos por un abismo, tal es la suerte del desterrado. [...]

Siempre que hemos leído la descripción que hace de su primera navegación de América a Europa hemos experimentado una emoción que no será común a todos los lectores, porque no todos podrán conocer el sentimiento y la verdad que encierran aquellas páginas. Pero ¡ay! Nosotros también hemos surcado aquellos mares; nosotros hemos visto el nublado cielo de las Bermudas, y hemos oído bramar los inconstantes vientos de las Azores. Como la célebre escritora hemos abandonado la tierra de nuestra cuna; hemos emprendido uno de aquellos viajes solemnes, cuyos primeros pasos reciben el Océano; y lleno el corazón de emociones de juventud, y rica imaginación con tesoros de entusiasmo, hemos contemplado la terrible hermosura de las tempestades, y la augusta monotonía de la calma en medio de dos infinitos.

Todas las impresiones que pinta la autora nos son conocidas: todos aquellos placeres, todos aquellos pesares los hemos experimentado. (Gómez de Avellaneda, 1844: (X-X) ${ }^{1}$

Tanto este prólogo como algunos de sus propios escritos evidencian un interés de Avellaneda por el género del relato de viaje que ha pasado hasta ahora casi por completo desapercibido para sus críticos; sólo García Morales (1986: 242), Raúl Ianes (1997: 212) y sobre todo Albin (2002) prestan atención a esta faceta de la escritura de Avellaneda, en relación con las Memorias inéditas (1838, ed. 1929) y en ocasiones con la serie de artículos «Mi última excursión por los Pirineos» (1860, ed. 1914). La razón de este aparente olvido radica en la difícil localización de dichos relatos, a excepción del ya citado de 1838, que fue editado por Domingo Figarola-Caneda de modo exento en 1914, y luego incluido en una recopilación de documentos sobre Avellaneda hecha por la viuda de Figarola-Caneda, Emilia Boxhorn, en 1929.

Los otros dos textos se publicaron en la prensa y la localización de ambos ha resultado un tanto azarosa. Se trata de la serie de artículos «Mi última

1. Roberto Ignacio Díaz (2002: 97) afirma que «The encounter with exile informs many of these author's writing, and, indeed, much of the canon of Cuban and Spanish American literatures». 
excursión por los Pirineos», que corresponde al viaje del verano de 1859, editada en el Diario de la Marina de La Habana en 1860 y luego recogida en el volumen VI de las Obras del centenario en $1914^{2}$, y de otra serie de artículos, hasta ahora olvidados, aparecidos en el periódico El Estado en 1857.

\section{LAS MEMORIAS INÉDITAS DE LA AVELLANEDA (1836-1838)}

Este es un texto de carácter memorialístico que la autora redacta basándose en «algunas notas que conservo en mi libro de Memorias» (Gómez de Avellaneda, 1838, ed. 1929: 249), con el auxilio de la memoria y en ocasiones de algunos libros como la «Descripción artística de la catedral de Sevilla» (1804) de Juan Agustín Ceán Bermúdez (Ibíd.: 275, 282). Avellaneda denomina a estas páginas «apuntaciones de mis viajes»:

Eloísa: alguna vez he ideado formar para ti apuntaciones curiosas de mis viajes, consultar a otros viajeros, tomar nociones acerca de la historia, tradiciones y particularidades locales de los sitios de que te hablo; en fin, hermosear estas Memorias que te he ofrecido, haciéndolas instructivas e interesantes; pero no he podido; fáltame la tranquilidad de espíritu necesario para esta empresa, y aun el tiempo de realizarla. (Ibíd.: 255)

Los sustantivos 'apuntes' y 'notas', que figuran con frecuencia en los títulos de los libros de viaje (Serrano, 1993), son también los que prefiere García Morales para el relato de Avellaneda (1986: 232). Albin (2002) opta por memorias de viaje para el mismo fin, incluso dice que «los cuadernos pueden leerse como un diario de viaje, el cual imita a la vez que se desvía de los relatos de los viajeros ilustrados de los siglos XVIII y XIX, en particular de los escritos de Alexander von Humboldt» (Albin, 2002: 35). Algunas notaciones temporales de las fechas precisas en que se escribe cada cuadernillo o de los días de permanencia en cada ciudad, podrían hacer pensar en el relato como diario, quizás siguiendo el modelo discursivo del Werther (1774). Más ajustadamente creo que podría tildarse de memorias de viaje, denominación que se adapta muy bien al carácter del texto, que podría haber sido un mero diario de viaje, pero que la autora prefiere elaborar para hacer un relato más meditado, en la línea de de la Histoire de la Soeur Ines (1832) y de Souvenirs et mémoires (1836) de la condesa de Merlin.

Este primer relato es el de escritura más temprana entre los que pergeñó la autora (está escrito en Sevilla entre el 7 de noviembre y el 8 de diciembre de 1838) y fue uno de los últimos en conocer la luz pública (se editó en 1914).

2. Me ha imposible encontrar el citado volumen en ninguna biblioteca europea; debo su hallazgo y consulta a la generosidad de la profesora Stella Maris Scatena. 
Se abre con una dedicatoria a su prima Eloísa de Arteaga y Loynaz, que es una mera excusa para establecer un diálogo, aunque la voz narrativa es única: no parece haber otro destinatario que la propia escritora, a pesar de las numerosas llamadas de atención a Eloísa. A la dedicatoria sigue la exposición del viaje, dividido en cuatro cuadernillos; en el comienzo de los cuadernillos tercero y cuarto se repite dicha dedicatoria. Con todo, no creo que pueda tildarse el relato de epistolar, como hace Albin (2002: 35), tal vez por la similitud de la voz narrativa con la de la llamada autobiografía editada en 1907 por Lorenzo Cruz de Fuentes.

El escrito a que me refiero relata en forma retrospectiva el viaje de Avellaneda desde Cuba a España en 1836, hasta llegar a instalarse en Sevilla en 1838, evocando nostálgicamente la isla que deja atrás; es un viaje en compañía: la de su hermano Manuel (al que cita en el segundo cuadernillo, durante la estancia en Vigo) y la de su madre, de la que se separa en Vigo para dirigirse a Andalucía, los compañeros de viaje durante la visita al castillo de las Bredas, o los amigos que la acompañan durante la estancia en Itálica; no obstante, sus observaciones son absolutamente individuales y no tienen nunca en cuenta a sus acompañantes.

Para Albin (2002: 38) estas Memorias tienen un carácter híbrido, ya que en ellas se encuentran trazos de varios discursos: desde el histórico, el político y el científico de los viajeros europeos (que la autora imita y somete a revisión) hasta el de la ensoñación poética inventada por Rousseau, y concluye que la autora elabora sus cuadernos desde los márgenes de la literatura de viajes, mediatizada por los discursos hegemónicos de la época: el científico, en especial el de la historia natural, y el histórico. Añade que la narración está permeada por un sustrato poético que se explicita en citas de José Amador de los Ríos, Lamartine, Byron, Heredia o Mme de Staël, en la evocación física del paraíso perdido y en las descripciones de la naturaleza sublime. Por otra parte, su discurso crítico sobre las ciudades y las costumbres europeas se inscribe en la corriente de crítica e interrogante sobre las ideas, creencias religiosas e instituciones políticas de la vieja Europa que tiene como modelo, entre otros, las Cartas persas de Montesquieu; no obstante, en la autora la crítica implícita contra el sistema colonial español no oculta su innegable atracción por España. El relato, por último, es a la vez, en opinión de Albin, un homenaje y un modo de socavar la imagen del padre poético de Avellaneda, Heredia, como poeta nacional; de este modo la escritora se autoafirma «como escritora que ha logrado borrar la imagen obstruyente de su precursor poético» (Ibíd.: 76). Albin incide, además, en los aspectos románticos del texto (Ibíd.: 54-62). 
El relato de 1838 está escrito en primera persona y posee un marcado carácter intimista, porque la autora no pensó nunca darlo a la luz pública y porque la contempladora se autodefine como un sujeto sensible, romántico, dominado por la fuerza de su imaginación, y que se deja arrastrar por la nostalgia de lo que deja atrás: « ¡Cuántas veces, mientras la oía, entregábame yo también a los recuerdos de mi hermosa Patria que acababa de abandonar, tal vez para siempre!» (Gómez de Avellaneda, 1838, ed. 1929: 251); y parafraseando el Marino Faliero de Casimir De la Vigne:

¡Oh patria! ¡Oh dulce nombre, que el destierro sólo enseña a apreciar! ¡Oh, tesoro que ningún tesoro puede reemplazar!... Yo he visto los trémulos rayos del sol reflejar en su golfo, yo he paseado su margen encantadora, yo he respirado su ambiente puro... y el cielo de otros países no es cielo para mí. (Ibid.: 278).

Bien es cierto que la descripción evoluciona desde la subjetividad de las notas del primer cuadernillo, que narran la travesía en el mar, a la objetividad y el detalle de las notas referidas a la ciudad de Sevilla, a la que dedica los dos últimos cuadernos, con lo que el relato pierde en emoción y gana en precisión.

\section{«MI ÚLTIMA EXCURSIÓN POR LOS PIRINEOS»}

En esta serie de artículos Avellaneda cuenta el viaje que hizo con su marido Domingo Verdugo desde Bilbao, pasando por Bayona y Biarritz, hasta Bagnères de Bigorre, y luego la vuelta a España, en el verano de 1859, enlazando con el viaje que les llevaría a Cuba. Se publicó en el Diario de la Marina de La Habana entre el 19 de junio y el 28 de julio de 1860, precedido de una carta de la autora al director del periódico y completado con una «Nota adicional» escrita en el potrero de la Esperanza en 1860. En la citada carta se revelan algunos datos sobre la gestación del relato:

Mi estimado amigo:

Como si presintiese que había de abandonar próximamente el suelo de la Europa, quise, en mi excursión veraniega del año último, recorrer los sitios más notables de los Pirineos españoles y franceses, tomando notas de las tradiciones que las poetizan. Mi propósito era escribir más tarde algunas curiosas páginas de impresiones y recuerdos para corresponder a los amigos que se reunían en mi modesta casa una vez por semana, amenizando nuestra pequeña reunión con la lectura de sus trabajos literarios inéditos [...]

Revueltos entre fárragos de manuscritos venían conmigo los ligeros apuntes tomados en mi indicada excursión, tan borrosos, por cierto, y tan poco inteligibles, que aun yo misma he necesitado esfuerzos de memoria para descifrarlos [...]

Mi primera intención de fundar sobre aquellas notas un extenso y agradable relato de mi última correría, realzando cuanto pudiera el interés de las 
tradiciones (recogidas en un país en que son tan abundantes), me pareció imposible después de haberse borrado de mi mente multitud de datos con que contaba para auxiliar los consignados en el papel, que eran, por desgracia, los menos. Pero a falta de bonitas narraciones podía dar a usted, amigo mío, los mismos apuntes destinados a servirles de base, pues lo que desmereciesen por incompletos y desaliñados, lo ganaran acaso por la sencillez y verdad que caracteriza todo lo que se escribe para mí misma, sin pretensiones de embellecer y abrillantar las cosas con ropajes de la fantasía. Esto pensé y esto hago. Ahí van mis borradores. Usted les dará el destino que mejor le parezca, como también a estas líneas que les sirven de encabezamiento. (Gómez de Avellaneda, 1860, ed. 1914: 17)

Sus destinatarios primeros iban a ser los amigos de su tertulia, que escucharían el relato leído; el destinatario final son los lectores periodísticos; pero en el discurso se apela indistintamente a unos y otros. Su objetivo primordial era el de recoger las tradiciones de las Provincias Vascongadas, lo que hace tanto en este relato como en el anterior de 1857, al que después me referiré. Su intención es construir algunas páginas de impresiones y recuerdos, apoyándose en sus borradores y con la ayuda de su memoria; a falta de tiempo, la autora dice ofrecer al lector los apuntes o borradores, «incompletos y desaliñados» pero no adornados; esta es también la excusa en el relato de 1838, por lo que quizás se trate de un tópico de modestia relacionado con la humilitas autorial. La tarea de reelaborar el texto es común a ambos relatos de viaje, que se cuentan de modo retrospectivo, y no al hilo del desplazamiento; el primero de ellos no se publicó en vida de la autora, pero se escribió al final de ese largo viaje (iniciado en 1836) tras el que acabaría instalándose en Sevilla (en 1838); el segundo vio la luz casi un año después de realizado dicho periplo (del verano de 1859 al de 1860).

La difusión periodística, por iniciativa de la propia autora, diferencia este relato y el otro que luego consideraré, del primero que he comentado, porque se hace evidente la intención de dar publicidad a lo escrito y porque su destinatario no es un lector individual sino colectivo.

La modalidad del relato de viaje periodístico fue habitual en la prensa decimonónica, como han señalado Rodríguez Gutiérrez (2003) y Rivas Nieto (2006: 155-179); a la retórica del mismo se ha referido Alburquerque (2006), que considera que esta modalidad pertenece tanto al ámbito histórico como al literario:

El relato de viajes no es sólo un libro de información sobre lugares y recorridos [...] El lector de este género acude allí en busca de otra cosa distinta. Sabe que el marco general del relato es verdadero, pero es consciente de que la narración allí contenida, no pende sólo del hilo de lo real, sino también del hilo de la imaginación del autor. Lo que principalmente interesa al lector de 
este tipo de libros es la visión particular del autor por encima del dato concreto, preciso, exacto. Y por esto mismo, el lector no exigirá nunca al autor responsabilidades acerca de lo descrito o contado. El lector no está interesado sólo y exclusivamente en el grado de verdad de lo que allí se nos narra, como podría exigírsele a un historiador o a un periodista o a un biógrafo. (Alburquerque, 2006: 171-172)

El relato se formaliza en un discurso, en un acto de lenguaje en el que

lo que cuenta es la visión propia del emisor, sus impresiones, las anécdotas, las noticias o los sucesos inventados, pero que pueden ilustrar mejor lo descrito. En definitiva, la asunción del modo «relato» es el rasgo primordial sobre el que se cimenta su virtualidad literaria. (Ibíd.: 184).

Además, la narración se inserta en la estela de otros escritos similares, que la autora recuerda: «Atravesando poblaciones de la pintoresca Guipúzcoa -que ya he hecho conocer a mis amigos en mis cartas de otros años-, llegamos a San Sebastián» (Gómez de Avellaneda, 1860, ed. 1914: 13-14), «Los bañistas inconstantes han abandonado en gran número sus amenas playas en los dos últimos años, para honrar las de Deva, que tuve la dicha de hacer más conocidas con mis cartas al periódico El Estado» (Ibíd.: 14)3.

Es un viaje en compañía, la de su esposo, la de los ciceroni o guías turísticos (en Bilbao, Lourdes, Cauterets-Saint-Sauveur, Cauterets-Gavarnie) y la de grupos de turistas, de entre los que destaca a los franceses:

No hay compañeros de viaje como los franceses: entusiastas, penetrantes, inteligentes, cosmopolitas por instinto y por educación, y poseedores de ese tacto exquisito que aprecia y comprende todos los caprichos del sentimiento y de la imaginación, ellos no se quejan nunca de las molestias de una penosa marcha, que saben amenizar con su verboso esprit. (Ibíd.: 26)

La presencia de estos compañeros de viaje y de su relación con ellos se hace notar en varias ocasiones, a diferencia de lo que sucedía en las memorias de 1838, mucho más centradas en el yo:

Tres días hacía apenas que nos hallábamos asociados a las doce o quince personas de la excursión a Gavarnie, y en tan corto número de horas reinaba ya entre todos, no esa intimidad de confianza afectuosa, a que somos propensos los españoles, pero sí la armonía de gusto, la comunión de impresiones, la recíproca necesidad de agradarnos, que ahuyentando contrariedades contribuían poderosamente a prestar encantos a nuestra expedición, y a hacernos sentir penosamente su término próximo. (Gómez de Avellaneda, 1860, ed. 1914: 26)

3. Se anuncia aquí el relato de viaje de 1857 que comentaré más adelante. 
El relato de 1860 ha sido comentado por Rodríguez García (1914: 449-452), Remos y Rubio (1945: 161), Ianes (1997) y Scatena (2007). Para Ianes (1997: 212) «podría ser calificado como una guía para viajeros», y reconoce en él un «propósito literario asociado con el recorrido turístico» (Ibíd.: 213).

Scatena (2007), tomando en consideración los dos relatos de viaje que he venido comentando, considera que el discurso de Avellaneda es ambivalente en la cuestión de las identidades española y cubana, mostrándose cubana en el texto de 1838 y española en el de 1860; afirma también que en sus escritos Cuba aparece como fuente de exaltación patriótica y España como fuente de inspiración literaria, y que ella pretende formar parte del canon de ambas literaturas; coloca las cosas en su sitio cuando dice que el debate sobre la cubanidad o hispanidad de Avellaneda se produce en vísperas del inicio de un gran movimiento a favor de la independencia de Cuba, y da muchos datos sobre la polémica suscitada al respecto en los siglos XIX y XX, tomando en cuenta las nuevas direcciones de la crítica que reivindican el legado de las escritoras latinoamericanas como contribución a los emergentes discursos nacionales.

\section{LOS ARTÍCULOS PUBLICADOS EN EL PERIÓDICO EL ESTADO}

La única noticia que he conseguido allegar sobre esta serie de artículos en la bibliografía de Avellaneda es la de Carlos M. Trelles (1920: 222), que cita como relatos de viaje de la autora las Memorias inéditas de 1914, «Mi última excursión a los Pirineos» (Diario de la Marina, 1860) y «Viaje a las Provincias Vascongadas» (1857); aunque la propia autora, en el relato publicado en 1860, ya proporcionaba la referencia al mismo (Gómez de Avellaneda, 1860, ed. 1914: 14).

Estos artículos corresponden al verano de 1857 y están escritos en forma de carta dirigida al escritor de origen cubano Teodoro Guerrero ${ }^{4}$, quien las tilda de «cartas íntimas de impresiones de viajes» (carta I); fueron publicados en la sección de «Variedades» del periódico El Estado los días 29 de julio, 30 de julio, 7 de agosto, 16 de agosto, 20 de agosto, 1 de septiembre y 6 de septiembre de 1857, con el título de «Impresiones de viajes», por lo que ocasionalmente tiene en cuenta la escritora a sus lectoras periodísticas: «a ver si me revelan alguna misteriosa tradición de estas costas de su imperio, con la cual pueda entretener a V. y a las amables suscritoras de El Estado, siquiera sea

4. A dos de las obras de este escritor de origen cubano les puso prólogo la escritora: Anatomía del corazón (1857) y Lecciones del mundo (1864); Guerrero, a su vez, le escribió una epístola en verso ( $\mathrm{L}$ La lira rota. Epístola a mi amiga Tula», 1860, en Figarola-Caneda, 1929: 142-144) y una necrológica que se publicó en La Ilustración Española y Americana, año XVII, no 8, de febrero de 1873, pp. 113, 123 y 126. 
al final de mi siguiente carta» (final carta IV). He conseguido localizar todas las entregas, excepto las cartas del 16 (IV) y del 20 de agosto (V); afortunadamente, la del 16 de agosto la reprodujo La Época el 18 de agosto de 1857, precedida de una nota que rezaba:

Nuestros lectores saben ya que la distinguida poetisa, señora Avellaneda, se halla en las provincias Vascongadas, y que a su pluma son debidas algunas bellas cartas que ha dado a luz El Estado. Creemos que nos agradecerán que reproduzcamos en La Época la siguiente, en que al mismo tiempo que se hace una linda pintura de los baños de Deva y de algunos otros pueblos de aquel país, se cuenta una de las crónicas de más palpitante y dramático interés que repiten los ecos de aquellas montañas. (Gómez de Avellaneda, 18 de agosto de 1857: 1)

Menos suerte he tenido con la carta V, de la que sólo he podido leer unos fragmentos que publicó J. de la Rosa el 21 de agosto de 1857 en La Iberia, además de una relación de Zacarías Casaval ${ }^{5}$ en La Época del 15 de agosto del mismo año, que proporciona también noticias indirectas de dicha carta y amplía un poco los fragmentos publicados en La Iberia. Casaval comienza:

La presencia en las provincias de escritores distinguidos, y entre ellos de la poetisa más inspirada de los tiempos modernos, ha producido el inestimable bien de que cada uno de esos sitios tan pintorescos sea objeto de bellos cuadros que formarán uno de los libros sobre impresiones de viaje más leídos de España, y que harán populares a la vez los baños del suelo cantábrico en Europa. Así la poesía y la literatura prepararán lo que más tarde, pero en un porvenir que ya divisamos, realizará el vapor, el día en que la España se vea por el ferro-carril del Norte enlazada a la Francia, a la Italia, a la Alemania y a la Europa. Deva, Arechavaleta, Santa Águeda, Bilbao, San Sebastián, serán entonces Ems, Spá, Biarritz y Bagnères de Luchon.

El articulista alaba sus descripciones de la naturaleza:

La Avellaneda es la única que puede bosquejar estos cuadros de la naturaleza, como Pedro Fernández el de la sociedad que acude a los baños de las provincias Vascongadas. Abandonando a ellos escenas que necesitan el pincel del poeta o la pluma humorista del escritor de costumbres... (Ibid.)

Narra a continuación una excursión realizada desde Deva hasta el caserío de Asau en falúa y luego en carreta a la que asistió Avellaneda, y donde recitó su poema «La pesca en el mar» (que reproduce) ${ }^{6}$, siendo coronada con laurel por

5. Abogado y periodista, autor de escritos de carácter político y fragmentos de una novela, Cosas de España, publicada en Revista de España.

6. La misma poesía la reproduce La Iberia el 16 de agosto de 1857. También Ramón de Navarrete (Pedro Fernández) coincidió con Avellaneda en las Provincias Vascongadas, como cuenta en una «Revista de baños» que se publica en La Época el 8 de agosto de 1857, y como relata Avellaneda en la carta II de las que nos ocupan. 
el joven poeta Santiago Liniers; el trayecto terminó en el pueblo de El Castañar, donde la poeta recitó finalmente unos versos en elogio de las mujeres españolas que pueblan las playas del norte ( Si de esas ondas saladas/tornara a salir Citeres, $\ldots \gg)$.

Además, fragmentos de la carta VI fueron publicados en La Iberia el día 3 de septiembre de 1857 por J. de la Rosa (descripción de la fiesta de los gansos) y la primera parte de la leyenda «La flor del ángel. Tradición vascongada» (carta VI) fue reproducida por La Época el 3 de septiembre de 1857, excepto el último párrafo, y completa en el diario La Discusión los días 2 y 8 de septiembre de 1857 , respectivamente.

Los libros y artículos sobre Impresiones de viaje, como este de Avellaneda, son frecuentes en la literatura decimonónica (Romero Tobar, 2000: 235); entre los libros pueden citarse los de Alejandro Dumas, Impresiones de viaje: en Suiza (1833), Impresiones de viaje: Sur de Francia (1841), Impresiones de viaje: El Cáucaso (1859), Impresiones de viaje: En Rusia (1860). Entre los artículos, los de Nemesio Fernández Cuesta, «Impresiones de viaje» (El Siglo Pintoresco, 10, 1845); Juan Antonio de la Corte, «Impresiones de viaje a Lisboa y sus contornos» (Semanario Pintoresco Español, junio-noviembre de 1847); Antolín Esperón, «Impresiones de viaje. Santander y provincias vascongadas» (Semanario Pintoresco Español, julio-agosto 1850), y Ramón Salazar y Mazarredo, «Impresiones de viaje. Cataluña» (La Época, septiembre-noviembre de 1859).

Por otra parte, la forma epistolar es habitual en los relatos de viaje, desde los humanistas de los siglos XV y XVI (Romero Tobar 2007: 480-481), y en particular durante los siglos XVIII (Rueda 2001) y XIX, v.gr. Lettres d'un voyageur américain (1823), Lettres d'un voyageur à l'embouchure de la Seine (1828), o Lettres d'un voyageur de George Sand, libro este último formado por una serie de artículos sobre sus viajes por Italia, Francia y Suiza a lo largo de tres años, publicados en la Revue des Deux Mondes entre mayo de 1834 y noviembre de 1836, y cuya primera edición en libro es de 1838 (Figuerola 2007). En la prensa española decimonónica se encuentran también algunos ejemplos ilustrativos como los artículos titulados «Viajes. Cartas 1 y 2», «Viajes. Carta 3» y «Viajes. Carta 4» (1845-1846) de José Heriberto García de Quevedo, aparecidos en El Siglo Pintoresco, y la serie de Concepción Gimeno de Flaquer titulada «Viaje a Valencia. Cartas a la señorita de Moya», publicada los días 30 de mayo, 10 de agosto y 20 de agosto de 1878 en la revista Cádiz.

Estos artículos recogen el relato de viaje de la autora por las Provincias Vascongadas en compañía de su esposo Domingo Verdugo y de otros compañeros ocasionales, como las cinco personas que en la carta III descienden con ella a la caverna de San Valerio, las compañeras de viaje de las cartas IV y V, 
y las familias y jóvenes que les acompañan en las últimas excursiones por el país en la carta VI. El resumen de las actividades que emprenden en grupo lo hace la escritora al final de la carta IV: «entre baños, paseos por la ría, comidas en el campo y reuniones amenas en el hermoso salón de la casa consistorial, se pasan volando las horas y los días, sin que pueda una hacer nada»; afirmación esta que no resulta cierta en su caso: hay muchos momentos para el ocio y el descanso, ya que ella escribe sus impresiones del viaje. Lo cierto es que la conversación, la comida y los paseos por una naturaleza en que el agua es presencia habitual (fuentes, ríos) son entretenimientos comunes tanto en el relato de 1857 como en el de 1860.

La inmediatez temporal singulariza esta narración frente a las otras dos, ya que aquí la distancia entre las fechas de viajes y excursiones y la escritura es muy breve. En la carta I, escrita el 5 de julio, comienza Avellaneda «Mi estimado amigo: diez días hace que me encuentro en estos baños»; la II se escribe el el 22 de julio con una disculpa por el retraso: «Hace diez y siete días, si mal no recuerdo, que me despedía de V., mi querido amigo, al acabar mi primera carta, ofreciéndole próximamente la segunda»; la III el 29 de julio, la IV el 9 de agosto, la fecha de la V la desconozco, la de la VI es del 20 de agosto, y la VII y última lleva la fecha del 30 de agosto.

\section{LAS TRADICIONES Y LA HISTORIA}

En «Mi última excursión por los Pirineos» la narración se hace desde la primera persona pero son varias las voces narrativas que se suman a la de la narradora principal, con lo que en el discurso se hace énfasis en la oralidad de las tradiciones relatadas. En los artículos de 1857 la voz narrativa es únicamente la de la narradora en primera persona que recoge por escrito tradiciones que ha escuchado, pero cuyos narradores no se mencionan; así dice en la carta IV sobre la de «La dama de Amboto»:

Aceptado, empero el incuestionable principio de que no hay que buscar talento en escritos que salen de semejantes oficinas, me atreveré a contar de cualquier modo una de las más dramáticas tradiciones que se conservan religiosamente archivadas en la imaginación novelesca de los vascongados, y cuyas particularidades curiosas las debo a un joven del país, sin nombre alguno todavía en la república de las letras, más que lo tendrá de seguro envidiable el día en que su excesiva modestia no le impida el pretenderlo ${ }^{7}$.

7. Este joven pudiera ser joven el escritor Sotero Mantelli, autor de una versión de la misma leyenda publicada en 1869. 
Los materiales narrativos imbricados en el relato responden siempre al nombre de tradiciones, algo que se sugiere en el de 1838 y se corrobora en los dos siguientes:

Alguna vez he ideado formar para ti apuntaciones curiosas de mis viajes, consultar a otros viajeros, tomar nociones acerca de la historia, tradiciones y particularidades locales de los sitios de que te hablo. (Gómez de Avellaneda, 1838, ed. 1929: 255),

Este país no tiene que envidiar a Escocia ni a Alemania, en punto a tradiciones. Apenas hay monte o ruina que no tenga la suya, más o menos romántica. (Gómez de Avellaneda, 1857: carta IV)

Quise, en mi excursión veraniega del año último, recorrer los sitios más notables de los Pirineos españoles y franceses, tomando notas de las tradiciones que las poetizan. (Gómez de Avellaneda, 1860, ed. 1914: 17)

En el volumen V de la edición de Obras literarias de 1871 Avellaneda utiliza el subtítulo de tradición para «La bella Toda y los doce jabalíes. Dos tradiciones de la plaza del mercado de Bilbao», «La montaña maldita. Tradición suiza», «La flor del ángel. Tradición vascongada» y «La dama de Amboto. Tradición vasca»; en la misma edición aplica el marbete de leyenda a «La velada del helecho o el donativo del diablo. Leyenda fundada sobre una tradición suiza», «La baronesa de Joux. Leyenda fundada en una tradición francesa» $\mathrm{y}$ «El cacique de Turmequé. Leyenda americana». En mi opinión, ambas denominaciones no se utilizan por parte de la escritora de modo indistinto, como parece habitual en el periodo romántico ${ }^{8}$, sino que se apuesta claramente por la de tradición, sobre todo cuando estas narraciones aparecen insertas en los relatos de viaje, tratando de ilustrar el carácter y costumbres de los pueblos recorridos mediante la relación de historias profundamente enraizadas en ellos.

Estas tradiciones son, en el relato de 1860: la de la brecha de Roland ${ }^{9}$, la de la iglesia de los Templarios en Gavarnie, la historia de $\mathrm{D}^{\mathrm{a}}$ Toda de Larrea,

8. Para el mismo concepto Millet (1997: 5) prefiere la denominación de legendario:

Le légendaire n'est pas un genre; c'est un dispositif. Un dispositif poétique de mise en relation, ou plutôt de soudure, du mythe et de l'Histoire, de la religión et de la politique, avec pour horizon la fondation de la communauté dans son unité. Ce dispositif qu'est le légendaire ne se confond donc pas avec la légende. La légende entre, avec le mythe, dans le dispositif du légendaire. Elle est même peu distincte du mythe (...) Le mot mythe cependant s'emploie au XIX siècle plutôt pour les fables païennes, tandis que le mot légende s'emploie plutôt pour les récits chrétiens et les poésies populaires (avec les «chansons» et les «ballades»).

9. El origen de este episodio podría estar en las laisses 171-173 de La chanson de Roland (quizás de la edición publicada en París en 1850 por F. Génil), aunque tal vez recurriera la autora a la leyenda IV de las recogidas por José María de Goizueta en sus Leyendas vascongadas (1856) con el título de «La bocina de Roldán» o al mismo episodio brevemente 
la de Elvira y Avendaño ${ }^{10}$, la de la muerte del infante D. Juan por D. Pedro I de Castilla ${ }^{11}$ y la de «La ondina del lago azul: recuerdo de mi última excursión por los Pirineos» ${ }^{12}$, de indudable filiación romántica esta última. Y en el de 1857: en la carta I la de las cruces de piedra donde están enterrados el conde de Oñate y el de Aramayona y la de la casa donde se cree que vivió el último descendiente varón del héroe de Villamar, Padilla; en la carta IV la dramática del palacio de Ozaeta y la de «La dama de Amboto» ${ }^{13}$; y en la VI la de «La flor

referido por Antonio de Trueba en su cuento «Desde la patria al cielo» (La América, 24 de enero y 9 de febrero de 1858; luego en Cuentos de color de rosa, 1859)

10. En la edición exenta del texto, incluida en las Obras literarias, esta tradición se resume junto con la de Doña Toda de Larrea en «La bella Toda y los doce jabalíes. Dos tradiciones de la plaza del mercado de Bilbao» (Gómez de Avellaneda, 1871: 61-74), adjudicándose la relación de ambas a la misma cicerone; además, la narración presenta diferencias sustanciales con respecto a la versión periodística en lo que se refiere a la primera tradición, que es en el texto exento mucho más amplia, y se sitúa en el verano de 1858 (si bien se incluye en el relato periodístico correspondiente al verano de 1859). En la edición de Obras literarias (1871: 54), además, el final funde ambas historias en una imagen: «En mi insomnio agitado me parecía estar mirando las lágrimas de la bella Toda, arrancada de su palacio con la divina excelenta, y la sangre de Avendaño corriendo bajo los pies de los furiosos jabalíes.»

11. La tradición sobre $\mathrm{D}^{\mathrm{a}}$ Toda de Larrea y sobre el asesinato del infante D. Juan las cuenta con mucho detalle Antonio de Trueba en «Los amores de un rey», La moda elegante ilustrada, 28 de abril de 1867, pp. 135-136. La de Elvira y Avendaño, junto con la de D. Juan y D. Pedro, las relata el mismo autor en «La torre de Bilbao La Vieja» (La Ilustración Española y Americana, 8 de septiembre 1874, pp. 523-526), si bien insiste sobre todo en la historia de la torre. La tradición de Doña Toda de Larrea la glosa Francisco Navarro Villoslada en la zarzuela en un acto y en verso La dama del rey (1955), y en una novela que no fue publicada hasta 1998 por Carlos Mata Induráin, titulada Doña Toda de Larrea o La madre de la Excelenta.

12. En la edición periodística un párrafo en que se presenta el Lago Azul abre paso, sin transición, a la narración. En la edición exenta incluida en las Obras literarias (Gómez de Avellaneda, 1871: 115-146) precede a la narración una introducción en que la autora sitúa el momento del relato en el verano de 1859 y el lugar en los Pirineos franceses, resume sus visitas desde Gavarnie hasta Bagnères de Bigorre y, finalmente, se atribuye la narración a un cicerone de nombre Lorenzo. La dama del lago tiene hondas raíces en el folclore europeo, sobre todo germánico; su aparición en literatura hay que vincularla a la materia de Bretaña del ciclo artúrico; en la contemporaneidad ha sido glosada en textos como La dama del lago (1810) de Walter Scott, Ondina del barón de la Motte-Fouqué (1811), Rusalka de Puchkin (1819), «Maitagarri» de José María de Goizueta (1856) y la leyenda becqueriana «Los ojos verdes» (Benítez 1970: 146-151). entre otros (Vega 2009); el asunto ha inspirado también las óperas de Hoffmann Ondine (1816) y de Rossini La donna del lago (1819), basada esta última en el poema de Walter Scott.

13. El texto que se edita exento en las Obras literarias (1871) es bastante diferente de este; parece haberse corregido a fondo, resultando más coherente, y está escrito con un estilo más cuidado; en él se insiste en el desplazamiento de María como heredera por su condición de mujer, al nacer su hermano Pedro, y en la situación de subordinación 
del ángel». Tales tradiciones son parangonables en interés a las del Norte de Europa, en opinión de Avellaneda: «Este país no tiene que envidiar a Escocia ni a Alemania, en punto a tradiciones.» (carta IV) ${ }^{14}$

La apuesta por la tradición es un modo de concebir y de recuperar la historia en un escritor como Gustavo Adolfo Bécquer:

El interés de Bécquer por los relatos tradicionales forma parte de su concepción de la historia. Las manifestaciones de la fantasía popular integran orgánicamente el contenido del Volksgeist o espíritu del pueblo. Como la historia, ayudan a reconstruir los eslabones perdidos de esa totalidad espiritual. (Benítez, 1970: 92).

Así lo ponen de manifiesto la Historia de los templos de España (las tradiciones religiosas en relación con los templos, como el del Cristo de la Vega o el del Cristo de la Luz), las leyendas (producto de la elaboración literaria de tradiciones orales o escritas; Ibíd.: 104, 107), algunos artículos periodísticos (que incluyen tradiciones inseparables de los lugares que visita, v.gr. «Roncesvalles» $\left.{ }^{15}\right)$ y las Cartas desde mi celda:

Sea cuestión de poesía, sea que es inherente a la naturaleza frágil del hombre simpatizar con lo que perece y volver los ojos con cierta triste complacencia hasta lo que ya no existe, ello es que en el fondo de mi alma consagro, como una especie de culto, una veneración profunda por todo lo que pertenece al pasado, y las poéticas tradiciones, las derruidas fortalezas, los antiguos usos de nuestra vieja España, tienen para mí todo ese indefinible encanto, esa vaguedad misteriosa de la puesta del sol en un día espléndido, cuyas horas, llenas de emociones, vuelven a pasar por la memoria vestidas de colores y de luz, antes de sepultarse en la tinieblas en que se han de perder para siempre. (carta IV, El Contemporáneo, 1864, en Bécquer 1995: 405)

También la literatura vasca pre-nacionalista hace un uso parecido de las tradiciones, al servicio, además, de una determinada imagen del pueblo vasco. Antonio Elorza ha señalado (1977: 360-365) que las tres líneas que configuran a lo largo del XIX los temas y argumentos del nacionalismo vasco son el fuerismo político (liberal-democrático pero más a menudo conservador), la literatura costumbrista (que acuña una imagen idealizada del mundo rural) y la fusión de una historiografía romántica nacionalista con la narración de

de la mujer y de privilegio del hombre. Por su parte, en la edición periodística, más característicamente «romántica», la fatalidad y la locura son fuerzas determinantes en el desarrollo de la trama; un párrafo referido a la locura de María se elimina de la versión segunda del texto.

14. Detalla muchas de estas tradiciones el artículo titulado «Supersticiones poéticas de La Escocia» publicado en El Museo de Familias, vol. 2, 1839, pp. 214-223.

15. En «Roncesvalles» (El Museo Universal, 28 de enero de 1866) incluye Bécquer fragmentos del romancero de Carlomagno (Bécquer 1995: 739-741). 
corte legendario (sustitución de la historia por la leyenda). Así, por ejemplo, Antonio de Trueba en el prólogo a El libro de las montañas:

Hay tanta poesía y tan sencilla grandeza en estas montañas euskaras que el pintor más esforzado y diestro se esforzará cuanto le sea posible en trasladarlas con fidelidad al lienzo y quedará descontentísimo de su obra. Estos valles perpetuamente verdes y hermosos, estos altísimos montes erizados de rocas y precipicios, estos mares casi siempre agitados y en gigantesca lucha con las montañas calcáreas que avanzan a su encuentro como desafiando su cólera; este pueblo tan amante de sus libertades y su dignidad, tan valeroso y fiero para defenderlas y al mismo tiempo tan pacífico, tan laborioso, tan leal, de costumbres tan dulces y puras, tan respetuoso ante Dios, ante la justicia humana y ante los ancianos; este antiquísimo, elocuente, original y dulce idioma [...]; este apego al hogar paterno y a las tradiciones de la familia, este espíritu de igualdad noble y sabiamente entendida; estas asambleas a la sombra de un árbol en que el pueblo se gobierna a sí propio hace más de mil años; estas singulares y misteriosas tradiciones que viven en cada caserío, en cada bosque y en cada roca; todo esto es tan grande y tan bello que el libro o el cuadro a que se haya querido trasladar por grande que parezca a los que no lo conocen, debe parecer muy pequeño a los que lo conocemos ${ }^{16}$. (Trueba, 1867: 9-10)

O Juan Venancio de Araquistain en el de sus Tradiciones vasco-cántabras:

Al dedicar al país en que tuve la fortuna de nacer, la colección de varias de sus antiguas tradiciones, parte de la sagrada herencia de nuestros padres, creo de mi deber exponer algunas consideraciones, acerca de la importancia histórica y moral de los cantos, leyendas y cuentos populares, que son el reflejo de las creencias y el eco fiel de los sentimientos de las generaciones pasadas. [...]

Las tradiciones dice el ilustre filósofo católico, el eminente historiador Cantú, «aunque parezcan insulsas o viciadas, proceden de algún hecho, o tienen su origen en una verdad profunda; de modo que no pueden mirarse con indiferencia por el que estudia en la historia, no la anécdota, sino al hombre.

Las tradiciones y cantos populares, añade Herder, son los archivos del pueblo, el tesoro de su ciencia, de su religión, de su cosmogonía; son la vida de sus padres, los fastos de su historia. (Araquistain 1866: 3-4)

En esta dirección apunta la inserción de tradiciones en los relatos de viaje de Gertrudis Gómez de Avellaneda, pero también, por ejemplo, su elogio al pueblo de Guernica en el relato de 1860, donde la autora parece simpatizar con los fueros vascos, que estuvieron vigentes hasta el final de la tercera guerra carlista en 1876; en este escrito alaba «el roble inmortal que representa la historia entera de aquella raza, modelo de patriotismo y de fidelidad a sus leyes, de aquel pueblo tan sobrio, tan constante, tan pobre, tan laborioso, que

16. Millet (1997: 14-45) considera características de lo legendario la ingenuidad y la simplicidad. 
se ha hecho digno de ser siempre hijo predilecto de la libertad y de la gloria» (Gómez de Avellaneda, 1860, ed. 1914: 12); describe la casa de juntas con todo lujo de detalles («el sencillo templo de la libertad vizcaína», Ibíd.: 13), imaginando incluso el ambiente que ha de rodear la deliberación de las juntas generales, se siente inspirada y escribe un poema al roble secular.

Reviste el mismo significado el canto de Altabiscar que se incluye en la carta VII, poema histórico que relata la derrota de las huestes de Carlomagno y su sobrino Roldán por los euskaldunes, que Avellaneda ofrece en una libre versión en romance endecasílabo castellano; versión que suscitó opiniones encontradas en los periódicos contemporáneos; en La Época el 10 de septiembre de 1857 se inserta esta noticia: «Nuestra insigne poetisa la señora Gómez de Avellaneda ha hecho una soberbia traducción en verso, casi literal, del magnífico Canto de Altabiscar, y está recogiendo preciosísimas tradiciones eusqueras»; y en La Iberia el 4 de octubre de 1857, a propósito de la colección de Leyendas vascongadas de José María de Goizueta, se dice:

No dejaremos tampoco de mencionar la traducción en verso que de El canto de Altabiscar ha hecho la señora Avellaneda, y que acaba de publicar El Estado, en el que se retrata con rasgos enérgicos el célebre paso de Roncesvalles, cuyo canto, si hemos de juzgar por otras dos versiones en prosa, que de él nos ha dado el señor Goizueta, ha perdido al ser puesto en verso por la inspirada poetisa parte de su primitiva energía y majestad.

Avellaneda cree que este canto es obra de un bardo euskera, como había afirmado el bayonés Eugène Garay de Monglave («Le chant d'Altabiscar», Journal de l'Institut historique, I, 1835,174-175), primer editor del texto en versión francesa, que más tarde reproduce también Francisque-Michel en Le pays basque. Sa population, sa langue, ses moeurs, sa littérature et sa musique (Paris, Librairie de Firmin Didot, 1857, pp. 236-238):

Necesita V. más todavía para participar de mi entusiasmo? Pues bien! Más le puedo decir ¡Sepa V. que este país ha tenido un Osian! Un gran bardo de los tiempos antiguos, cuyas agrestes armonías no tienen nada que envidiar a los cantos de los Scaldas ni a ninguno de los mejores trozos de la poesía escandinava. (carta VII)

Tal atribución no es sino una superchería literaria (Bidador, 2000: 303), ya que el cantar está inspirado en los poemas ossiánicos, algo que parece intuir Avellaneda en la cita que acabo de aducir.

Algunas notas costumbristas en el relato de 1857, como la referencia a los bailes populares (v.gr. el zorzico) en carta $\mathrm{V}$, o al festejo de los gansos en carta VI, completan el ambiente popular. Por otra parte, las valoraciones sobre el pueblo en este mismo relato de 1857 tienen un tono tan idealizado como en los escritos de Trueba, v.gr.: 
Dígame V. si no bastan ellas para hacer admirar la rica imaginación de este pueblo, único acaso en España por la sencillez de sus costumbres primitivas y por el orden imponderable de su administración especial, a la que debe entre otros beneficios, el de ver cruzado su territorio en todas direcciones por magníficas carreteras, tanto más dignas de admiración cuanto han sido más difíciles de construir por las condiciones topográficas del país. (carta VII)

Pese a la importancia de las tradiciones, la historia reciente esta también presente. En el relato de 1860 se mencionan la aparición de la Virgen a Bernadette en Lourdes (acaecida entre febrero y julio de 1858); en Bayona y Biarritz la historia se hace presente por medio de Napoleón III, Eugenia de Guzmán y su hijo, personajes estrechamente vinculados a estos lugares; en Pau se recuerda a Abd-El-Kader, prisionero en el castillo de dicha localidad en 1848 y liberado en 1852 por el príncipe Luis Napoleón; en varios momentos, en fin, se recuerda la última guerra civil (la primera guerra carlista, acaecida entre 1833 y 1839, puesto que la segunda -1846- 1849-, tuvo como escenario Cataluña). En el de 1857 se recuerda la visita que en 1845 hizo la reina Isabel II junto con su madre y su hermana a los baños de Santa Águeda y caverna de San Valerio (carta III) y el abrazo de Vergara entre Espartero y Maroto que dio fin a la primera guerra carlista (carta IV).

\section{LITERATURA DE BALNEARIO Y CRÓNICA SOCIAL}

Los relatos de 1857 y 1860 están construidos desde la perspectiva del turista y/o bañista de balneario; la saludable costumbre del turismo termal es habitual para la escritora:

Después de haber tomado él las célebres aguas de Panticosa, y terminado yo mi anual excursión por los baños de Guipúzcoa- determinamos visitar la provincia de Vizcaya, pasando de ella a Bayona y recorriendo en seguida una parte de los Pirineos franceses. (Gómez de Avellaneda, 1860, ed. 1929: 7)

El turismo termal cuenta con una larga historia, si bien en la modernidad se desarrolla a partir del siglo XVIII y sobre todo en el XIX en lugares como Panticosa, Deva, Santa Águeda, o el alto Pirineo francés; a esta última zona acudieron ya en el siglo XVIII, creyendo en el poder curativo de sus aguas (en particular las de Bagnères de Bigorre) personajes como la condesa de Aranda, Pablo de Olavide, Pedro José de Yeregui, el marqués de Mora o madame Krüdener (Olaechea: 1985). En el XIX contribuyó a consolidar dicha costumbre la presencia en las Provincias de la familia real, sobre todo a partir de mediados de siglo, y también de algunos viajeros como Francisco de Paula Madrazo, que dejó testimonio de ella en Una expedición a Guipúzcoa en el verano de 1848 (Madrid, 1849). Al turismo termal fue asimismo muy aficionada Emilia Pardo 
Bazán, asidua concurrente a los de Vichy, Mondariz y La Toja, desde donde escribió algunas crónicas ${ }^{17}$.

La literatura de balneario fue también fecunda, como lo testimonia la novela de Emilia Pardo Bazán Un viaje de novios (1881), en que se convierte en ficción la materia que habitualmente forma parte de relatos de viaje y escritos de parecida índole:

En septiembre del pasado año 1880, me ordenó la ciencia médica beber las aguas de Vichy en sus mismos manantiales, y habiendo de atravesar, para tal objeto, toda España y toda Francia, pensé escribir en un cuaderno los sucesos de mi viaje, con ánimo de publicarlo después. Mas acudió al punto a mi mente el mucho tedio y enfado que suelen causarme las híbridas obrillas viatorias, las «Impresiones» $\mathrm{y}$ «Diarios» donde el autor nos refiere sus éxtasis ante alguna catedral o punto de vista, y a renglón seguido cuenta si acá dio una peseta de propina al mozo, y si acullá cenó ensalada, con otros datos no menos dignos de pasar a la historia y grabarse en mármoles y bronces. Movida de esta consideración, resolvíme a novelar en vez de referir, haciendo que los países por mí recorridos fuesen escenario del drama. (Pardo Bazán, 1881, ed. 1971: 57)

De la misma forman parte también algunos cuentos de Clarín como El caballero de la mesa redonda (primera ed. incompleta 1886; segunda ed. 1895) o El dúo de la tos (1894) y la novela de Armando Palacio Valdés La hermana San Sulpicio (1889), ambientada en el balneario de Marmolejo. Más tarde Azorín recogería en Veraneo sentimental (1944) las crónicas que realizó para el periódico $A B C$ en el verano de 1904, contando su recorrido por algunos balnearios del norte, desde el vasco de Cestona hasta el gallego de Mondariz.

El relato de Avellaneda de 1860 no tiene como objetivo primordial el termalismo sino la observación del entorno; no obstante, hay en él apreciaciones sobre los establecimientos balnearios, v.gr:

La situación de Elorrio es bellísima (...) aun sin la riqueza de las aguas minerales que posee, debería atraer gran número de forasteros durante la estación calurosa. El establecimiento de baños sulfurosos es tan bueno como los de Santa Águeda, Arechavaleta, Alzola y Cestona, favoreciéndole durante toda la temporada numerosa concurrencia. Las fuentes ferruginosas abundan

17. V.gr. «La vida contemporánea. Mondariz», La Ilustración Artística, 22 de agosto de 1898; «La vida contemporánea. Salud en el fango. La Toja», La IIustración Artística, 4 de septiembre de 1899. El viaje es presencia habitual en la prosa de Emilia Pardo Bazán: en sus diarios de viaje (González Herrán, 1999; Freire, 2008) y en sus crónicas periodísticas que luego pasan a ser libros de viaje (Freire, 1999; Jiménez Morales, 2008). Algunas de estas, sin embargo, no fueron recogidas en libro, como la serie de cuatro artículos publicados en la revista madrileña Letras de molde entre enero y marzo de 1900 (Rubio Jiménez, 2001), en los que la autora relata un periplo por tierras murcianas.

Anales, 23, 2011, pp. 323-351 
también, lo mismo que en Guipúzcoa, operándose transformaciones maravillosas con el uso de ellas en las personas linfáticas y de pobre constitución. (Gómez de Avellaneda, 1860, ed. 1914: 13)

No es en verdad extraña la predilección que obtiene de los bañistas la pequeña capital de aquel departamento de los altos Pirineos, pues, como antes dije, ningún sitio termal reúne la variedad de aguas que enriquecen a Bigorre. El Gran Establecimiento contiene baños de las fuentes de la Reina, del delfín, de San Roque, de Foulón, de Rock-Lagnes, de Carrère Lagnes y de los Ojos.

Otros llenan sus pilas con los caudales de la Fuente Nueva-Laguthière, Grand Pré, Lasserre, Mora, Theas, Pinac, Salut, pequeño Barrègues, Versalles, y quizá algunas más que no recuerdo. De las nombradas fuentes, unas son frías, otras más o menos calientes, y las hay sulfurosas, salinas, ferruginosas y aún creo que acídulas.

En todos los establecimientos encuentra el bañista comodidades no comunes, y en el de Frascatti recreos de todo género, pues reúne salón de música, gabinete de lectura, billar, café, jardines, etc. (Ibíd.: 29)

El de 1857 sí tiene como objetivo el termalismo, por lo que en él se detallan las estancias en los balnearios de Santa Águeda (descrito con gran minuciosidad en carta I) y Aramayona (breve descripción en carta II), sin que alcance la autora a describir el de Arechavaleta, pendiente de una segunda visita al mismo que no llega a realizar:

El edificio a cuya puerta me han detenido un momento las tristes reflexiones anteriores, no presenta en su aspecto nada de notable, ni hace presumir las comodidades que se gozan en su interior. Los baños y la casa hospedería están en el mismo edificio, constando aquellos de catorce pilas o bañeras en gabinetitos claros y ventilados, si bien la circunstancia de ser dichas bañeras todas de mármol negro, y no tan espaciosas como desearíamos los bañistas corpulentos, les presta cierta semejanza lúgubre. Los corredores en que nos paseamos, esperando que esté dispuesto el baño, no son tampoco muy dignos de la grandiosidad del establecimiento, y en este punto, el cercano de Arechavaleta (del que hablaré a V. en otra) lleva al que describo considerable ventaja. Cada pila tiene dos grifos para agua fría y caliente, que pasa a ellos por medio de una bomba sin perder nada de sus propiedades, sucediendo lo mismo en las calderas en que se calienta. Hay también dos baños de vapor y los aparatos necesarios para los de chorro y regadera. La casa hospedería consta de tres pisos, en cada uno de los cuales se encuentra una espaciosa galería con cuartos a un lado y otro, hasta el número de 60. [...]

En el piso bajo se hallan dos magníficos salones, de 96 pies de largo y 28 de ancho, ambos decorados con elegancia, y sirviendo el uno de comedor principal, y el otro de punto de reunión para la sociedad, que celebra en él sus agradables soirées. Hay en el mismo piso sala de billar, gabinete de tresillo, dos comedores de segundo orden, varios cuartos para criados, y las cocinas, repostería, lavadero y otras dependencias de la casa. (carta I) 
Uno de los aspectos de la vida de balneario que más seduce a Avellaneda es el trato social, sobre el que insiste repetidamente en sus relatos. En el de 1838 se refiere a la sociedad de La Coruña y a la sevillana de la plaza del Duque. Mucho más por extenso se detiene en ella en los dos siguientes; en «Mi última excursión por los Pirineos» describe la sociedad bilbaína en el teatro y en el paseo, la sociedad en Biarritz (con la presencia de Napoleón III y Eugenia de Montijo) y la de balneario en Cauterets o en Bagnères de Bigorre:

Veis constantemente circular por las calles aquella población anual de ciudadanos de todas las naciones, presentando tipos de todas las clases: príncipes rusos que ostentan el lujo nacional en magníficas carretelas; despreocupadas damas inglesas que con escurridos trajes de Mahón y sombreros de anchas alas se dirigen al baño, o a paseo, en pacíficos jumentos; ancianos enfermos y perezosos que son conducidos en cómodas sillas de mano; cabalgatas de jóvenes elegantes de ambos sexos que haciendo galopar briosos corceles y luciendo toilettes de fantasía, emprenden excursiones por los risueños valles del contorno.[...]

En ninguna parte es la vida tan sibarita como en Bigorre. Nadie piensa más que en divertirse. Bailes, comedias, conciertos, festines campestres sobre la hierba, a la sombra de seculares hayas, tiro de pistola en que hombres y mujeres compiten en destreza, deliciosos paseos a pie, excursiones magníficas en carruaje, a caballo o asno, todo se sucede incesantemente en aquella sociedad de elegantes ociosos. (Gómez de Avellaneda, 1860, ed. 1914: 28-30)

Pero es en la narración del viaje de 1857, ambientada en balnearios de las Provincias Vascongadas, donde más se extiende la autora en detalles sobre la vida social, dado que cuenta con numerosas relaciones entre los concurrentes. La carta II presenta el aspecto de una crónica de sociedad, citándose incluso al cronista Ramón de Navarrete:

Figúrese V., pues, si tan numerosa y grata sociedad, reunida bajo un cielo apacible, en un país hermosísimo, con la franqueza propia del carácter español, aumentada por la intimidad y la confianza de la vida campestre, puede y debe desarmar la más adusta misantropía. Aquí, donde se pone justamente en ridículo a cualquiera que pretende distinciones; aquí donde se respira en la atmósfera algo que predispone al gozo y a la expansión, y donde no pueden menos de parecer de mal tono la gravedad ceremoniosa y el aislamiento estudiado; aquí fraternizamos todos en poquísimo tiempo, y hasta las rarezas de algunos contribuyen a aumentar el buen humor de los otros. No está, empero, limitada al círculo de las personas que he nombrado la sociedad de que se goza en Santa Águeda, pues hay casi continuas comunicaciones entre estos bañistas y los de otros establecimientos no distantes. Gracias a esta agradable costumbre, hemos tenido el gusto de que comiesen con nosotros, hace algunos días, varios de los huéspedes de Arechavaleta, entre los que se hallaba nuestro distinguido amigo el Sr. de Navarrete, que mientras se 
lamenta Madrid del mutismo de Pedro Fernández, él viene a hacerle acopio de noticias y aventuras para sus amenas cartas del otoño.

Muchos individuos de la sociedad contemporánea madrileña coinciden en el balneario de Santa Águeda, entre ellos la señora y señoritas de Cueto, las habaneras Conchita Polo y su tía la Sra. de Aguado, el conde de Belascoaín (José Joaquín García del Castillo), el de la Vega y el de Treviño, el abogado Mariano de Oteiza, el ex -diputado Sr. de Herreros, su esposa e hijas, la señora y señorita de Campuzano, la señora doña Luisa Mateo de Zorrilla, el marqués de Albudeite, el de Gaviria y el de Espinardo, la hermana del general Van-Halen, el magistrado Gonzalo del Río, los señores de Santa Ana y de Murua, el militar Joaquín de Jovellar, el joven Soane (primogénito del conde de Velle), el hijo del marqués de Perales, los señores Bazán, Satorre, Enciso Ruiz, Martínez Baño, Peña y otros. Por otra parte, a su amigo el brigadier Barcaiztegui lo visitan en Arechavaleta, donde también se encuentran el conde de Altamira, los condes de Oñate, los marqueses de Tamames, la hija del general Rivero, la viuda de Álvaro y la señora y señoritas de García Goyena; y desde Elorrio acude a visitarla la poetisa Matilde de Orbegozo. En la carta III, durante su estancia en Mondragón, se desplaza con su esposo a la residencia del Sr. de Gorozave, hermano político de Pedro de Egaña. En el final de la carta IV se refiere a esa «numerosa sociedad, no menos selecta que divertida». En la $V$ cuenta algunos de los entretenimientos que comparten en las fiestas de Deva:

La merienda nos esperaba en la hermosa pradera que aquí llaman del Asau, y por la que presto revolaron como lindas mariposas mis alegres compañeras. Se bailó el zorcico (en el que tomé parte), al compás del tamboril y la flauta, y hasta se ensayaron lanceros y galops. [...] el zorcico es un baile muy lindo y muy airoso, en el que se hermanan la gravedad del minué con la alegría de la jota, y que lo desempeñamos a las mil maravillas en la risueña pradera del Asau. Llegó su turno al gaudeamus, y sentados sobre el florido césped despachamos en un abrir y cerrar de ojos enormes moles de helados, bizcochos, dulces, etc. Pero aún faltaba lo mejor y más inesperado para mí. ¡Fui coronada! Sí, señor. Fui solemnemente coronada por la mano de un niño, que será un gran poeta dentro de algunos años, y que en el acto de ceñirme la aromosa guirnalda, tejida allí mismo por las hábiles y lindas manos de las damas de la reunión, improvisó una elegante estrofa que siento mucho no poder recordar.

Y en la VI continúan los festejos en los que se reúne una numerosa concurrencia:

Concluida la descrita gansada tuvimos baile, como de costumbre, en el salón del consistorio, y aquello fue el término de las decantadas fiestas de la Asunción. Pasaron, como todo en la tierra, mi buen amigo, y desde el siguiente día comenzó a dispersarse la alegre sociedad bañista. Sin embargo, todavía nos hemos reunido recientemente con las familias de Paz y Membiela, García Goyena, Liniers, Aguilera, Palacios, Robledo, Lezcano, y con la simpática Sra. 
Moreno y varios jóvenes, resto de los muchos que animaban antes nuestras excursiones, y recorrimos juntos, por última vez acaso, los sitios más bellos del país. Sí: todavía hemos surcado alegremente las apacibles ondas de la ría, oyendo repetir al eco de las montañas los deliciosos acentos de la inspirada artista que ya he nombrado, y que nos deja para ir a ser la joya del teatro de la zarzuela en Alicante. Todavía hemos celebrado otra inolvidable merienda, saltando de la lancha en el paraje más umbroso de las pintorescas riberas, y agrupándonos bajo las unidas copas de los nogales frondosos y de las encinas seculares, que formaban sobre nuestras cabezas un extenso toldo de verdura. Todavía, en fin, hemos orado juntos en una de esas solitarias capillitas campestres que tanto dicen a mi fantasía.

\section{EL NUNCA CONTADO VIAJE DE 1858}

En este año debió de hacer Avellaneda un viaje similar a los de 1857 y 1859, empezando por las Provincias Vascongadas, siguiendo por Francia, y volviendo a España por Perpiñán, para quedarse luego una temporada en Barcelona y después en Valencia. Este viaje lo hizo también la escritora en compañía de su esposo Domingo Verdugo, que había resultado gravemente herido a raíz del incidente provocado en el estreno de su obra teatral Los tres amores.

El viaje de 1858 puede rastrearse en las noticias sueltas de la prensa y en algunas cartas personales. En La España el 2 de julio de 1858 (García) se lee: «Ayer debieron de salir de Madrid con dirección a las Provincias y después al extranjero la Sra. Dña. Gertrudis Gómez de Avellaneda y su esposo el Sr. D. Domingo Verdugo»; y en La Época, el 27 de agosto: «La Sra. Da Gertrudis Gómez de Avellaneda y su esposo el Sr. Verdugo, salieron el domingo de madrugada para los baños de Elorrio, en donde beberá sus aguas el antiguo coronel herido alevosamente no ha mucho en Madrid. Pronto verá la luz pública algún escrito de la insigne poetisa que se refiera exclusivamente al señorío de Vizcaya.» (Juanco, 27 de agosto de 1858).

Una carta de la autora a Pedro Antonio de Alarcón, fechada en Barcelona el 5 de noviembre de 1858, y que este publicó luego en el periódico La Discusión (Gómez de Avellaneda, 10 de noviembre de 1858) informa sobre su estancia en la ciudad catalana, su próxima marcha a Valencia para pasar allí el invierno, algunos proyectos literarios y, finalmente, el homenaje que recibió por parte de los coros Clavé, acompañados de la orquesta del Liceo.

Algún dato más proporciona Enrique Gil, en unos apuntes biográficos escritos para el volumen I de las Obras literarias de la autora en 1869:

Salvado milagrosamente de la muerte el simpático Sr. Verdugo, emprendieron ambos, a fines del verano, un viaje a los Pirineos, donde debía tomar el convaleciente las aguas que le aconsejaban sus médicos; y después de haber recorrido gran parte de aquel hermoso país, los viajeros -que habían entrado en 
Francia por Bayona -regresaron a España por Perpiñán, permaneciendo una temporada en Barcelona, donde los hospedó afectuosamente su ilustre amigo el Excmo. Sr. D. Domingo Dulce, hoy marqués de Castelflorite. (Gil,1869: XXXIV)

Los resultados literarios de este viaje los cuenta Avellaneda en una carta de 22 de noviembre de 1858, a un amigo catedrático que le había enviado sus discursos sobre las Provincias Vascongadas (Cotarelo, 1930: 29) ${ }^{18}$ :

Efectivamente, tengo escritas, aunque en borrador todavía, una composición poética Al árbol de Guernica, como también algunas páginas sobre el porvenir del Norte de España, que pensé publicar en algún periódico de Madrid. Desgraciadamente, el estado delicado todavía de mi marido y mis propios padecimientos desde hace días me han obligado a suspender todo trabajo por ahora, siendo ya muy probable que no dé a la prensa ningún escrito mío hasta la primavera próxima, en que los médicos permitirán ya a Verdugo el volver a la coronada villa. Mientras permanezcamos en Valencia, cuyo clima esperan sea ventajoso a mi enfermo, quizá no me ocupe en otra cosa que en mi comenzada obra La España contemporánea; pero no por ello pondré en olvido a mis amadas Provincias Vascongadas, que también tendrán lugar muy distinguido en el nombrado libro, algunas de cuyas páginas serán dedicadas exclusivamente a los adelantos que deben aquellas a su admirable administración ${ }^{19}$.

Tal vez también correspondan a este año esas «notas de mi viaje por Cataluña» que Avellaneda cita en «Mi última excursión por los Pirineos» (1860, ed. 1914: 14).

A la vista de estos testimonios parece evidente que Avellaneda, por impedimentos más que comprensibles, no publicó en el verano de 1858 el correspondiente relato de viaje. ¿Es posible que tanto la poesía al árbol de Guernica como la tradición de «La bella Toda y los doce jabalíes», a los que se atribuye fecha de 1858, fueran recogidas ese verano y publicadas en el relato editado en 1860? Así parece.

\section{EL VIAJE TOCA A SU FIN}

Los tres relatos considerados, en su diversidad, constituyen un testimonio indiscutible del tributo de Gertrudis Gómez de Avellaneda a la moda del relato de viaje, una moda perfectamente reglamentada:

La literatura tiene sus modas ni más ni menos que los vestidos. Introdujo Eugenio Sue una novedad a los Misterios, y cata ahí que la Europa entera la

18. Tal vez el catedrático del Real Seminario de Vergara Antonio de Aguirrezábal, autor de una Memoria acerca del porvenir de las Provincias Vascongadas con motivo de la construcción de los caminos de hierro, publicada en Bilbao en 1857.

19. El mencionado libro de Avellaneda, La España contemporánea, nunca llegó a publicarse. 
adopta [...] Tocóle el turno al diablo y entonces llovieron endiabladas producciones [...] En pos siguieron las memorias y no ha habido títere que no haya querido ahorrar a la posteridad el trabajo de romperse la crisma en busca de noticias de un personaje tan importante como era el autor de su propia biografía. Ahora están en moda los viajes, y la literatura tiene siempre a la puerta un caballo ensillado, botas de montar debajo la cama y un tren especial en el camino de hierro a su disposición. Y tal es la manía que ha cundido, que hasta yo ¡mísero de mí! Que me había librado de escribir memorias, diabluras y misterios no pude evadirme de caer en la tentación de escribir viajes. (A., 20 de agosto de 1853: 804-805)

Dicha moda encuentra en el turismo de balneario una de sus fuentes primordiales:

Comprendí empero que el mandar a los enfermos a tomar aguas está de moda entre la medicina moderna, y que el ir muchos sanos a tomarlas, es consecuencia de que la buena sociedad exige que en verano las personas de gusto no puedan estar sanas. La cabal salud es en los meses de junio, julio y agosto un beneficio de muy mal tono. Sano o enfermo, decidíme al fin por las aguas. (Ibíd.: 805)

Para tal efecto lo primero que hace el viajero es proveerse «de un gran librote en blanco, vulgo álbum, en cuya portada y con letras tamañas como el puño trazara el orgulloso título de Impresiones de viaje.» (Ibíd.)

Con todos estos prolegómenos, contando con las limitaciones materiales del viaje por estas fechas (recorridos lentos por malos caminos, en carruaje, diligencia o coche particular, en caballerías o a pie), proveyéndose de guías y acompañantes, y probablemente con las consabidas guías de diligencia y del bañista como apoyo, emprende Gertrudis Gómez de Avellaneda unos viajes de los que luego deja un testimonio literario escrito, sea o no en el preceptivo álbum (para el caso sirven lo mismo el libro de memorias que se menciona en el relato de 1838, el libro de apuntes citado en el de 1860, o las cartas del de 1857). Tales viajes aúnan variedad de materiales narrativos a los que concede cohesión la mirada de una narradora romántica que sublima el entorno contemplado y lo reproduce en términos pintorescos e incluso fantásticos (en particular en el relato de 1857), mediatizada como se halla su contemplación por la concepción idealizada del pueblo vasco y del entorno natural y por algunos referentes literarios. Con todo ello, dichos relatos de viaje evidencian su condición de género fronterizo, híbrido, de gran diversidad genérica y discursiva, trufados de elementos heterogéneos en una suerte de relato-miscelánea en que la aventura del viajero es un pretexto para hilvanar piezas diversas (Champeau, 2004: 28). 


\section{BIBLIOGRAFÍA}

A., «Caricaturas de viaje. I. De mi casa a la Puerta Nueva», El Áncora, 20 de agosto de 1853, pp. 804-806.

AlBin, María C., «Género, imperio y colonia: las Memorias de viaje de Gertrudis Gómez de Avellaneda», en Género, poesía y esfera pública. Gertrudis Gómez de Avellaneda y la tradición romántica, Madrid, Trotta, 2002, pp. 35-76.

AlbuRQUeRQUe GARCía, Luis, «Periodismo y literatura: el «relato de viajes» como género híbrido a la luz de la pragmática», en AA.VV., Retórica, literatura y periodismo. Actas del V. Seminario Emilio Castelar, Cádiz, Ayto. de Cádiz/Universidad de Cádiz, 2006, pp. 167-176.

ARAQUistain, Juan Venancio de, Tradiciones vasco-cántabras, Tolosa, Imprenta de la Provincia, 1866.

BÉCQUer, Gustavo Adolfo, Obras completas II, Madrid, Turner, 1995.

BENítez, Rubén, Bécquer tradicionalista, Madrid, Gredos, 1970.

BIDADOR, Joxemiel, «El euskara y la literatura en lengua vasca en la obra de Arturo Campión», Fontes Linguae Vasconum: Studia et documenta, 102, 2000, pp. 299-320.

CASAVAL, Zacarías, «Una excursión marítima por las aguas de Deva», La Época, 15 de agosto de 1857, p. 3.

CHAMPEAU, Geneviève, «El relato de viaje, un género fronterizo», en AA.VV., Relatos de viaje contemporáneos por España y Portugal, Madrid, Verbum, 2004, pp. 15-31.

COTARElo, Emilio, «La Avellaneda y sus obras», BRAE, tomo XVIII, cuaderno LXXXI, febrero de 1930, pp. 5-71.

DíAz, Roberto Ignacio, Unhomely rooms. Foreign tongues and Spanish American Literature, Bucknell University Press, Lewisburg, 2002.

ElorzA, Antonio, «El tema rural en los orígenes literarios del nacionalismo vasco», en Actas del Quinto Congreso Internacional de Hispanistas, coord. de François López et al., Burdeos, Université de Bordeaux III, vol. I, 1977, pp. 355-376.

ENA BORDONADA, Ángela, «La memoria del viaje: Viajes y libros de viajes de escritoras españolas del primer tercio del siglo XX», en AA.VV., Mujer y memoria: representaciones, identidades y códigos, ed. de $\mathrm{M}^{\mathrm{a}}$ José Porro Herrera y Blas Sánchez Dueñas, Córdoba, Servicios de Publicaciones de loa Universidad de Córdoba, 2009, pp. 103-134.

Figuerola, M. Carme, «George Sand, o cuando el talento del escritor se alía a la curiosidad del viajero», en AA.VV., Literatura de viajes y traducción, ed. de Francisco Lafarga et al., Granada, Editorial Comares, 2007, pp. 147-159.

Freire López, Ana M. ${ }^{a}$, «Los libros de viajes de Emilia Pardo Bazán: el hallazgo del género en la crónica periodística», en Salvador García Castañeda (ed.), 
Literatura de viajes. El Viejo Mundo y el Nuevo, Madrid, Castalia-Ohio State University, 1999, pp. 203-212.

— «Un cahier de voyage inédito de Emilia Pardo Bazán», La Tribuna, año 6, nº 6 , 2008, pp. 129-144.

GARCÍA, Antonio, «Gacetilla», La España, 2 de julio de 1858, p. 4.

García Morales, Alfonso, «Visión romántica de Andalucía en Gertrudis Gómez de Avellaneda. La «Autobiografía» de 1838», en Andalucía y América en el siglo XIX. Actas de las V jornadas de Andalucía y América (Universidad de Santa María de la Rábida, marzo 1985), Sevilla, 1986.

GIL, Enrique, "Adición a los anteriores [Apuntes biográficos]», en Obras literarias de la Sra. Dña. Gertrudis Gómez de Avellaneda. Colección completa. Tomo primero, Madrid, M. Rivadeneyra, 1869, pp. XXIX-XLII.

Gómez de AvellanedA, Gertrudis, Memorias inéditas de la Avellaneda (18361838), anotadas por D. Figarola Caneda, Habana, Imp. «El siglo XX», 1914, en Domingo Figarola-Caneda, Gertrudis Gómez de Avellaneda. Biografía, bibliografía e iconografía, incluyendo muchas cartas, inéditas o publicadas, escritas por la gran poetisa o dirigidas a ella, y sus memorias, notas ordenadas y publicadas por Doña Emilia Boxhorn, Madrid, SGEL, 1929.

— «Apuntes biográficos de la Sra. Condesa de Merlin», en condesa de Merlin, Viaje a La Habana, Imprenta de la Sociedad Literaria y Tipográfica, La Habana, 1844, pp. V-XVI.

- La Avellaneda. Autobiografía y cartas de la ilustre poetisa hasta ahora inéditas (1839), con un prólogo y una necrología por Lorenzo Cruz de Fuentes, publícase a expensas de la Ilma. Sra. Da María de Córdova y Govantes viuda de Cepeda, Imprenta y Papelería de Miguel Mora, Huelva, 1907.

— «Variedades. Impresiones de viaje», El Estado, 29 de julio, 30 de julio, 7 de agosto, 16 de agosto, 20 de agosto, 1 de septiembre, 6 de septiembre de 1857

— «Folletín. Un drama vascongado», La Época, 18 de agosto de 1857, pp. 1-2.

— «Variedades», La Discusión, 2 y 8 de septiembre de 1857, pp. 2-3.

— «Variedades», La Época, 3 de septiembre de 1857, p. 1.

- Carta del 5 de noviembre de 1858, La Discusión, 10 de noviembre de 1858.

— «Mi última excursión por los Pirineos» (Diario de la Marina, 19 de junio a 28 de julio de 1860), en Obras. Tomo VI. Miscelánea, La Habana, Imprenta de Aurelio Miranda, 1914, pp. 7-47.

- Obras literarias de la Sra. Dña. Gertrudis Gómez de Avellaneda. Colección completa. Tomo primero, Madrid, M. Rivadeneyra, 1869.

- Obras literarias de la Señora Doña Gertrudis Gómez de Avellaneda. Colección completa. Tomo 5: Novelas y Leyendas, Madrid, M. Rivadeneyra, 1871.

GonzÁlez Herrán, José Manuel, «Un inédito de Emilia Pardo Bazán: «Apuntes de un viaje. De España a Ginebra (1873)», en AA.VV., Literatura de viajes. El Viejo Mundo y el Nuevo, Madrid, Castalia, 1999, pp. 177-187. 
IANES, Raúl, «La esfericidad del papel: Gertrudis Gómez de Avellaneda, la condesa de Merlin, y la literatura de viajes», en Revista Iberoamericana, vol. LXIII, $\mathrm{n}^{\circ}$ 178-179, enero-junio 1997, pp. 209-218.

JimÉnez Morales, Ma Isabel, «Emilia Pardo Bazán, cronista en París (1889)», Revista de Literatura, 2008, julio-diciembre, vol. LXX, nº 140, pp. 507-532.

JuANCO, José, «Noticias generales, La Época, 10 de septiembre de 1857, p. 4.

- «Noticias generales», La Época, 27 de agosto de 1858, p. 4.

Millet, Claude, Le légendaire au XIXe siècle. Poésie, mythe et vérité, Paris, PUF, 1997.

NAVARRETE, Ramón de, «Revista de baños», La Época, 8 de agosto de 1857, p. 2.

OlaecheA, Rafael, Viajeros españoles del XVIII en los balnearios del alto Pirineo francés, Zaragoza, Colegio Universitario de La Rioja, 1985.

PARDO BAZÁn, Emilia, Un viaje de novios (1881), Barcelona, Labor, 1971.

RAMOS MATíAS, José Ignacio, «Bibliografía de libros de viaje por Euskal Herria en las bibliotecas institucionales de Vitoria-Gasteiz», Sancho el Sabio, 15, 2001, 199-240.

Remos y Rubio, Juan J., Historia de la literatura cubana, Cárdenas y Compañía, 1945, vol. 2.

RIVAS NiETO, Pedro Eduardo, Historia y naturaleza del periodismo de viajes desde el antiguo Egipto hasta la actualidad: mitos, relatos que describen el mundo para reyes y plebeyos, y cronistas, Madrid, Miraguano, D.L. 2006.

Rodríguez García, José A., De la Avellaneda. Colección de artículos, Habana, Imprenta «Cuba intelectual», 1914.

RODRÍGUEZ GutIÉRREZ, Borja, «La literatura de viajes en cinco revistas literarias madrileñas de la década de 1840», Torre de los Lujanes, nº 50, mayo 2003, pp. 67-84.

ROMERO TOBAR, Leonardo, «Viaje y géneros literarios», en AA.VV., Valle-Inclán (1898-1998). Escenarios. Seminario Internacional Universidade de Santiago de Compostela, noviembre-diciembre de 1998, ed. de Margarita Santos, Luis Iglesias, Javier Serrano y Amparo de Juan, Santiago de Compostela, Universidad de Santiago de Compostela, 2000, pp. 221-238.

- «La epistolaridad en los libros de viaje», en AA.VV., Escrituras y reescrituras del viaje. Miradas plurales a través del tiempo y de las culturas, Bern, Peter Lang, 2007, pp. 477-487.

RosA, J. de la, «Gacetilla. ¿Es poetisa o poeta?», La Iberia, 21 de agosto de 1857, p. 3.

— «Fiesta de los gansos», La Iberia, 3 de septiembre de 1857, p. 3.

- «Variedades. Leyendas vascongadas por José María de Goizueta», La Iberia, 4 de octubre de 1857, p. 1.

RuBio JimÉNEZ, Jesús, «Un viaje olvidado de Emilia Pardo Bazán «Por tierras de Levante»», Murgetana 105 (2001), pp. 93-111. 
RuEdA, Ana, Cartas sin lacrar. La novela epistolar y la España ilustrada, 1789-1840, Frankfurt, Iberoamericana-Vervuert, 2001.

SCATENA FRANCO, Stella Maris, «Gertrudis Gómez de Avellaneda entre Cuba e Espanha: relatos de viagem e ambivalencias em torno da questao da identidade nacional», Varia historia, v. 23, n. 38, jul/dez. 2007, pp.1-19.

SERRANO, María del Mar, Las guías urbanas y los libros de viaje en la España del siglo XIX. Repertorio bibliográfico y análisis de su estructura y contenido (Viajes de papel), Barcelona, Publicacions de la Universitat de Barcelona, 1993.

Trelles, Carlos M., Biblioteca geográfica cubana, Matanzas, Imp. Juan F. Oliver, 1920.

TruebA, Antonio de, El libro de las montañas, Bilbao, Librería de Agustín Empériale Editor, 1867.

VEGA, Pilar, «Todas las hadas tienen su lago: geografía fantástica de la leyenda literaria en el Romanticismo español», Belphegor, vol. VIII, n 2, septiembre de 2009.

Fecha recepción: 10/03/2010

Fecha aceptación: 07/05/2010 